\title{
Visualização in vitro da colonização de raízes por rizobactérias
}

\author{
Brigida P. V. de Queiroz ${ }^{1}$; Carlos I. Aguilar-Vildoso²; Itamar S. Melo ${ }^{3}$
}

${ }^{1}$ Centro Universitário Salesiano de São Paulo, Liceu Coração de Jesus, Rua Dom Bosco, 100 - 13466-440, Americana-SP, Brasil; ${ }^{2}$ Alellyx Applied Genomics, Techno Park, Km 104 Rod. Anhanguera, R. James Clerk Maxwell 320, 13069-380, Campinas, SP; ${ }^{3}$ Embrapa Meio Ambiente, CP-69 - 13820-000, Jaguariúna-SP, Brasil - Bolsista do CNPq. <itamar@embrapa.cnpma.br> Data de chegada: 13/12/2001. Aceito para publicação em: 07/06/05.

\begin{abstract}
Queiroz, B. P. V.; Aguilar-Vildoso, C. I.; Melo, I. S. In vitro visualization of colonization of roots by rhizobacteria. Summa Phytopatologica, v. 32, p. 95-97, 2006.

For in vitro colonization to be quickly verified, substrate transparency is important. With this objective, a simple method was modified and the visualization of rhizobacteria in the roots was correlated to their colonization via scanning electron microscopy (SEM). Seeds of Citrus limonia Osbeck were inoculated and monitored in glass tubes with different substrates (Agar-Agar, Agar Noble and Phytagel).

chia coli DH5a was used as the negative control. Phytagel allowed a clearer visualization of the colonization along the roots by the bacteria and a higher sensibility for the confirmation of the rhizobacteria. Roots that presented turbidity around the agar exhibited an efficient surface colonization when observed in high magnification. This method showed to be a very good tool to study the root colonization via SEM.
\end{abstract} Seven rhizobacteria strains were evaluated, and an isolate of Escheri-

Keywords: Citrus limonia, rhizobacteria, root colonization.

\section{RESUMO}

Queiroz, B. P. V.; Aguilar-Vildoso, C. I.; Melo, I. S. Visualização in vitro da colonização de raízes por rizobactérias. Summa Phytopatologica, v. 32, p. 95-97, 2006.

É proposto nesse trabalho a utilização do substrato phytagel para a germinação de sementes bacterizadas e visualização de colônias bacterianas. Sementes de limoeiro cravo (Citrus limonia Osbeck) foram inoculadas e monitoradas com rizobactérias utilizando-se tubos de ensaio contendo diferentes substratos para germinação de sementes, quais sejam: Ágar-Ágar, Ágar Noble e Phytagel, onde foram avaliados sete isolados rizobacterianos além de um isolado de Escherichia coli DH5a como controle negativo. Verificou-se que o Phytagel permitiu uma vi- sualização nítida da colonização ao longo das raízes, pelas bactérias, como também proporcionou ser uma boa ferramenta para estudar a colonização via microscopia de varredura. As rizobactérias que melhor colonizaram as raízes e que apresentaram turbidez no ágar, ao seu redor, mostraram-se aderidas à superfície radicular, com colonização eficiente em diferentes sítios ao longo das raízes, quando observadas em alta magnificação.

Palavras-chave: Rizobactérias, Citrus limonia, Colonização radicular.

Vários métodos in vitro têm sido desenvolvidos para se observar a colonização de raízes por bactérias antagônicas como, por exemplo, o uso de tubos de ensaio com solo (4) e placas com solo, ágar e papel de filtro (2). Entretanto, o emprego do Ágarágar (3) ou do Ágar Noble (1) permite o monitoramento visual das rizobactérias, principalmente no que se refere a sua habilidade de sobrevivência utilizando apenas os exsudatos radiculares.
Desta forma, estas metodologias facilitam a seleção de um grande número de isolados rizobacterianos. A colonização do rizoplano pode ser visualizada pela formação de uma turbidez de aspecto leitoso, que se forma ao longo das raízes, em conseqüência do crescimento bacteriano. Portanto, quanto mais transparente o meio, melhor a visualização da colonização. Assim sendo, os substratos citados acima apresentam uma turbidez 
natural, que em certos casos, interferem na sensibilidade do teste.

O objetivo principal do presente trabalho foi comparar os substratos Phytagel (Sigma), Ágar-ágar (Difco) e Ágar Noble (Difco), quanto à visualização da colonização de raízes de limoeiro 'Cravo' (Citrus limonia) por rizobactérias e, desta forma, facilitar a seleção de isolados rizobacterianos por um método de triagem simples.

Sete isolados bacterianos (Pseudomonas fluorescens C1/ SNa, P. fluorescens 2-3.1A, P. putida Sta. Bárbara, Chryseobacterium sp. 2-3.1L, Paenibacillus polymyxa 3-4, Serratia marcescens R 3-5 e S. indologenes 6-5.3) obtidos da rizosfera de feijoeiro, cenoura e citros, pertencente à Coleção de Culturas da Embrapa Meio Ambiente e o isolado DH5a de Escherichia coli, foram avaliados quanto à sua capacidade de colonizar raízes de citros.

Sementes de limoeiro "cravo", desinfestadas superficialmente, foram inoculadas com uma suspensão de inóculo $\left(70^{7}\right.$ a $10^{8}$ UFC) e, então, semeadas em tubos de ensaios contendo os seguintes substratos: Ágar Noble: água $(0,8 \%$ p/v), Ágar-Ágar e Plytogel-água. Duas sementes por tubo de $150 \mathrm{~mm}$ comprimento por $25 \mathrm{~m}$ de diâmetro foram usadas e 5 repetições por isolado bacteriano. Os tubos foram deixados em estufa a $28^{\circ} \mathrm{C}$ com fotoperíodo de 12 horas, e avaliados, periodicamente, considerando-se os seguintes parâmetros: germinação das sementes, presença de pêlos radiculares, tamanho e comprimento da raiz e colonização radicular. Aos $26^{\circ}$ dia de incubação, os substratos foram observados com relação a sua transparência e a presença das bactérias ao redor do sistema radicular. A comprovação da colonização se deu via Microscopia Eletrônica de Varredura (MEV) modelo Leo 982. Para isto, segmentos de raízes foram fixados em glutaraldeído $2 \%$ em tampão fosfato de sódio $0,1 \mathrm{M}$, desidratados por uma série alcoólica $(15,30,60,70,95$ e 100\%), secos ao ponto crítico e metalizados com fina camada de ouro.

Em todos os substratos utilizados foi possível a visualização da colonização das raízes (Figura 1). No entanto, os substratos utilizados, Ágar-ágar e Ágar Noble, por apresentarem uma turbidez natural, prejudicaram a visualização da colonização. Além disso, o Ágar Noble apresenta o inconveniente de ser oneroso. O Phytagel teve uma maior sensibilidade na detecção da bactéria no sistema radicular, onde se pôde, visualmente, ou com auxílio de microscópio estereoscópico detectar o crescimento bacteriano ao longo das radículas. Este é um meio extremamente transparente que facilita a triagem rápida de um grande número de linhagens, com potencial de colonizar o sistema radicular.

Considerando os resultados em Phytagel, P. putida (Sta. Bárbara) e Chryseobacterium sp. (2-3.1L) apresentaram uma colonização abundante e $P$. fluorescens (C1/SNa e 2-31A), Serratia marcescens (R 3-5), P. fluorescens (3-6) e Paenibacillus polymaxi 3-4 uma colonização intermediária. Escherichia coli não apresentou esta característica colonizadora ou estava abaixo do limite de detecção pela metodologia aqui utilizada. De fato, bactérias do grupo das Pseudomonas fluorescentes têm se destacado como potentes colonizadoras da rizosfera. A ausência de qualquer fonte de carbono disponível nos substratos utilizados proporciona uma seleção de rizobactérias com capacidade de utilização dos exsudatos radiculares, permitindo, assim, selecionar aquelas que são atraídas e/ou que metabolizam os exsudatos radiculares. Aquelas linhagens que apresentam abundante crescimento nas raízes, ao serem visualizadas por MEV, apresentaram aderidas e com forte colonização de diversos microsítios (Figura 2). Os resultados indicam que houve uma correlação entre a visualização da colonização da rizosfera via tubos de ensaio e do rizoplano via MEV. Desta forma, a seleção de colonizadores poderá ser simples, rápida e com baixos custos.

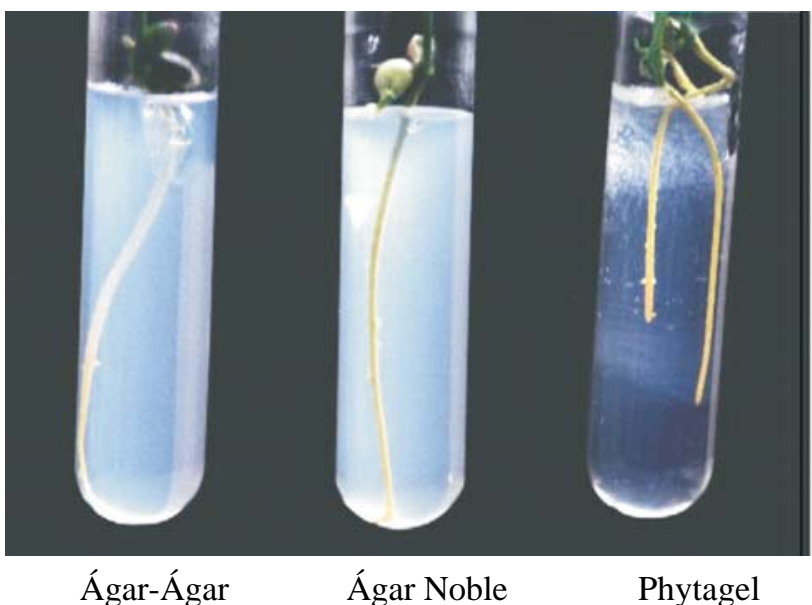

(a)

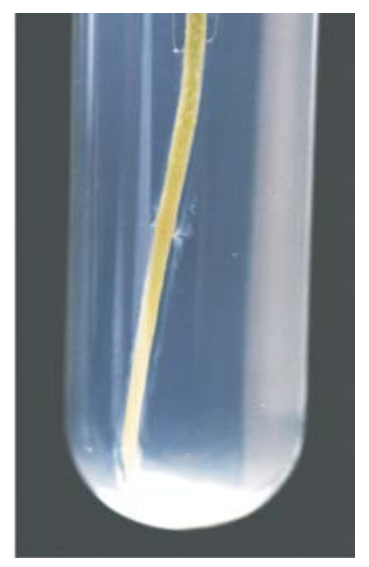

Phytagel com isolado 6-5 (b)

Figura 1. Aspecto das raízes de limoeiro 'Cravo' (Citrus limonia) colonizadas por rizobactérias em diferentes substratos, 26 dias após a inoculação das sementes. (a) Ágar-ágar com isolado 6-5.3 de Serratia indologenes; Ágar Noble, isolado 2-3.1L de Chryseobacterium sp e Phytagel isolado 2-3.1Ade P. fluorescens. (b) Detalhe da colonização, ao longo da raiz, do isolado 6-5.3 de Serratia indologenes no substrato Phytagel. 

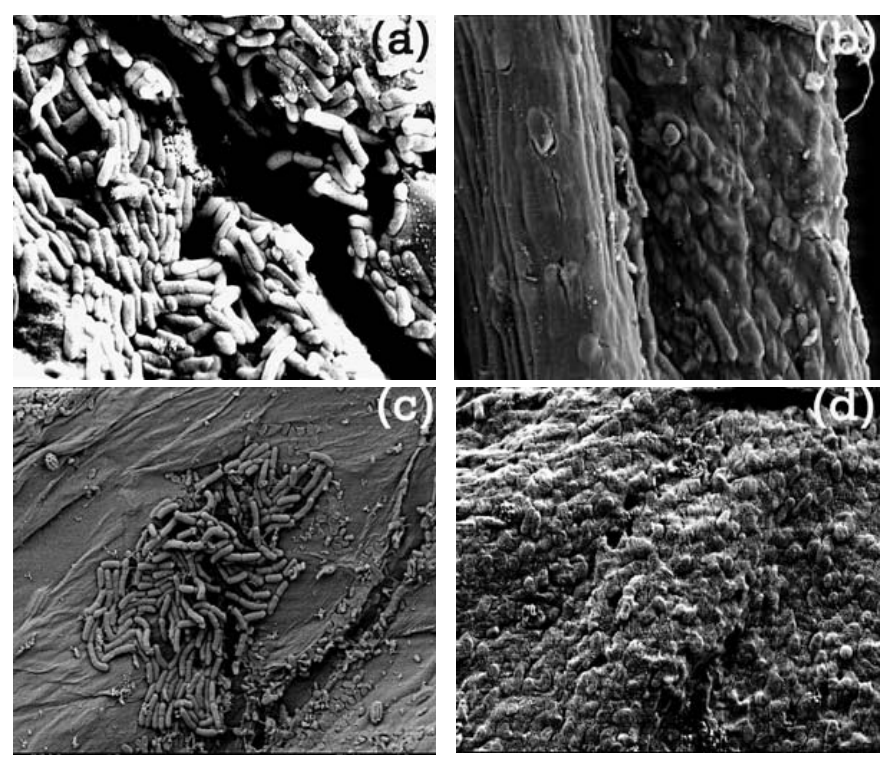

Figura 2. Microscopia Eletrônica de Varredura: (a) Células de Paenibacillus polymixa $3-4$ aderidas à coifa de raízes de citros $(5750,10 \mathrm{kv}$ $5 \mu \mathrm{m}$ ); (b) isolado 2-3 1L de P. fluorescens mostrando uma densa camada mucilaginosa $(5.000 \mathrm{x}, 5 \mathrm{kv}, 5 \mu \mathrm{m})(\mathrm{c})$ isolado 2-3 1L de Chryseobacterium sp agrupados em colônias no sistema radicular $(5.000 \mathrm{x}, 5 \mathrm{kV}$, $5 \mu \mathrm{m})$. (d) isolado C1-S/Na de P. fluorescens sob uma camada mucilaginosa $(390 \mathrm{x}, 15 \mathrm{kV}, 100 \mu \mathrm{m})$.

\section{REFERÊNCIAS BIBLIOGRÁFICAS}

1. Habe, M.H.; Uesugi. Método in vitro para avaliar a capacidade colonizadora de bactérias em raízes de tomateiro. Fitopatologia Brasileira, Brasília, v.25, n.4, p.657-660, 2000.

2. Randhawa, P.S.; Schaad, N.W. A seedling bioassay chamber for determining bacterial colonization and antagonism on plant roots. Phytopathology, St. Paul v.75, n.3, p.254-259, 1985.

3. Romeiro, R.S.; Takatsu, A.; Uesugi, C.H.; Moura, A.B.; Silva, H.S.A. Um método simples para seleção de rizobactérias com capacidade de promover colonização de raízes e sua implicação na indução de resistência sistêmica a enfermidades e na promoção do crescimento de plantas. Fitopatologia Brasileira, Brasília, v.24, n.1, p. 255, 1999. (Resumo 57)

4. Scher, F.M.; Ziegle, J.S.; Kloepper, J. A method for assessing the root-colonizing capacity of bacteria on maize. Canadian Journal of Microbiology, Ottawa, v.30, p.151-157, 1984. 